\title{
The Effect of Selected Cultivation Factors on the Growth of Mycelium of Pleurotus cystidiosus Miller
}

\author{
Luiza DAWIDOWICZ*, Agnieszka JASIŃSKA, Marek SIWULSKI \\ Poznań University of Life Sciences, Faculty of Horticulture and Landscape Architecture, Department of Vegetable Crops, Dąbrowskiego Street \\ 159,60-594Poznań,Poland; loocy7@op.pl ('correspondingauthor); jasinska.a@gmail.com; marek.siwulski@up.poznan.pl
}

\begin{abstract}
Pleurotus cystidiosus occurs in natural areas in North America. Its carpophores are characterized by a slightly sweet and mild taste. Fruiting bodies of $P$. cystidiosus are valued as source of nutrients and biologically active substances. The aim of the study was the selection of the optimal incubation temperature and the best substrate for the fastest mycelium growth. Two cultivars of P. cystidiosus - B1 and B122 was taken. Incubation of mycelium was performed in the temperature range from 15 to $30^{\circ} \mathrm{C}$. The influence of a substrate made of wheat straw, hemp shives and energetic grasses - Panicum virgatum and Miscanthus $\times$ giganteus. The experiment compared the growth of mycelium on a substrate with wheat straw (control sample) and with wheat straw and the addition of hemp shives and energetic grass in increasing amounts: 10, 20 and 30\%. It has been shown that the growth of mycelium of tested strains on different substrates varied. The best growth of mycelium occurred on the substrate with wheat straw and the addition of hemp shives, P. virgatum and M. $\times$ giganteus in the amounts of $20 \%$ and $30 \%$. The temperature of incubation also had a significant impact on the growth of the mycelium of $P$. cystidiosus. The optimal temperature was $25^{\circ} \mathrm{C}$. An investigation of the mutual dependence between morphological and qualitative characteristics of the type of agar medium allows optimization of the production of $P$. cystidiosus. The development of a low-cost and simple method for the production of $P$. cystidiosus can contribute to the introduction of this species into intensive cultivation. Use of waste materials in mushroom production will significantly increase the profitability of crops and reduce their costs.
\end{abstract}

Keywords: cultivation of edible mushrooms, energetic grass, hemp shives, incubation temperature, mycelium, organic substrate, oyster mushroom, wheat straw

\section{Introduction}

Pleurotus cystidiosus belongs to the kingdom of Fungi, phylum Basidiomycota, class Agaricomycetes, order Agaricales, family Pleurotaceae, genus Pleurotus. This species was first identified in North America by O. K. Miller in 1969. In literature, the name Miller's Oyster Mushroom, The Abalone Mushroom and the Maple Oyster Mushroom can be found as well as a Japanese name Obiratake and Chinese name bao yu gu (Hanelt, 2001; Stamets, 2011).

Cap of $P$. cystidiosus convex to hemispherix, eventually plane, measuring $2-5 \mathrm{~cm}$ wide and cream to off-white in colour. Cap edge often irregular. Gills broad, sometimes widely spaced, strongly deccurent with irregular edges. Stem thick, centrally or eccentrically attached and relatively short (Fig. 1). The mycelium of $P$. cystidiosus resembles an oyster strain - white, racing linearly, soon fluffy white and aerial.
But $P$. cystidiosus produces darkly pigmented arthroconidia forming a black pigment on the mycelium or basidiomata. As it grows outwards, black droplets form, radiating outwards from the centre as the mycelium matures. These are coremia - stalk-like cells whose tops are fitted with liquid droplets of black spores (Fig. 2) (Petersen et al., 1997; Zervakis, 1998; Croan, 2004; Bao et al., 2004; Lechner et al., 2004; Selvakumar et al., 2008; Abdullah et al., 2012; Usami et al., 2014; Stamets, 2011).

In natural conditions, $P$. cystidiosus occurred on all continents except Antarctica (Vilgalys et al., 1996; Zervakis and Balis, 1996; Lechner et al., 2004). It has a widespread distribution on angiosperm wood. In a natural environment it is encountered on dead tree stumps especially deciduous trees. P. cystidiosus occurs often in the form of groups consisting of several larger and smaller specimens that arise from a common base or imbricately are arranged one above the other (Moncalvo, 1995; Zervakis et al., 2004).

In cultivation, $P$. cystidiosus can be grown on substrates prepared on a base of straw and various types of agricultural, 
horticultural, forestry and textile industry waste (Cohen $e t$ al., 2002; Croan, 2004; Lau et al., 2013; Usami et al., 2014). It is cultivated mainly in Asia, particularly in China, Thailand and Taiwan (Hanelt, 2001; Stamets, 2011; Usami et al., 2014).

The caps and stems of $P$. cystidiosus are edible. In addition to the culinary qualities of fruiting bodies, $P$. cystidiosus has a high nutritional value (proteins, fibre, minerals and vitamins) and the content of biologically active substances with proven health-promoting properties. The biological activity of these mushrooms has been confirmed in several laboratory tests and clinical trials, which showed, among others, their antitumor, anti-inflammatory, antiallergic, antiatherosclerotic, antibacterial, antiviral, antifungal, immunomodulatory and hepatoprotective properties as well as lowering blood sugar levels and the effect of blood cholesterol This mushroom is low in calories due to the limited content of lipids (Manzi and Pizzoferrato, 2000; Wasser, 2002; Croan, 2004; Thekkuttuparambil and Kainoor, 2007; Karaman et al., 2010; Abdullah et al., 2012; Patel et al., 2012; Lau et al., 2013; Siwulski et al., 2014; Usami et al., 2014).

Earlier documentation states that oyster mushrooms can be grown on a variety of waste materials, such as: various types of straw and sawdust, cotton waste, chopped and corn stover, waste from the production of palm oil, tea leaves, chopped cocoa pods (Vilgalys et al., 1996; Croan, 2004; Lau et al., 2013; Usami et al., 2014). During the last few years, there has been a very dynamic development in the production of edible and medicinal mushrooms. This development was mainly caused by the ready availability of low-cost, waste materials from the agricultural, textile and wood processing industries, which may suggest a potential base for their crops including the cultivation of $P$. cystidiosus. Due to the increasing scarcity of cereal straw, a lot of research is undertaken to find an alternative substrate. It may be the straw of energetic grasses that is grown with an emphasis on maximum biomass. Energetic grasses can be used as an easily available substrate. In a similar way, the problem with hemp shives, the waste from the textile industry, can also solved. Hemp shives, in addition to the substrate, reduces the percentage of pathogenic infections. Use of these waste materials in oyster mushroom production will significantly increase the profitability of the crop and reduce its costs. There will also be a new way to solve the waste problem. Development of a low-cost and simple method for the production of $P$. cystidiosus may contribute to the introduction of this species into commercial cultivation. Determination of the morphological and qualitative characteristics of this type of substrate and growing conditions allow optimizing production in order to obtain the best yield of fruiting bodies with the best characteristics, for consumption and as a raw material for obtaining biologically active substances (Vilgalys et al., 1996; Siwulski and Sobieralski, 2004; Sobieralski et al., 2011; Usami et al., 2014; Dawidowicz and Siwulski, 2017).

Research of this project was intended to clarify the mechanisms of growth of mycelium of $P$. cystidiosus depending on various factors, especially the temperature of incubation and the type of substrate. The aim of the

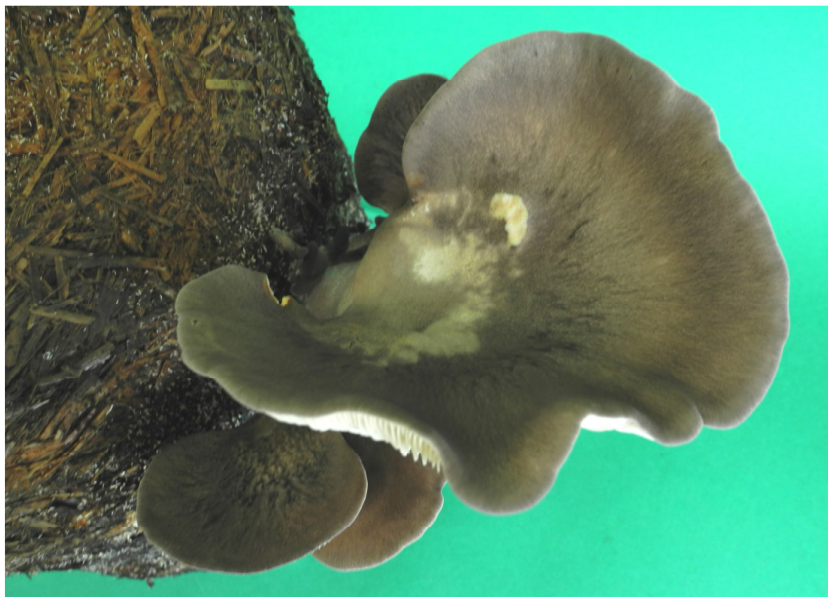

Fig. 1. Fruiting bodies of P. cystidiosus

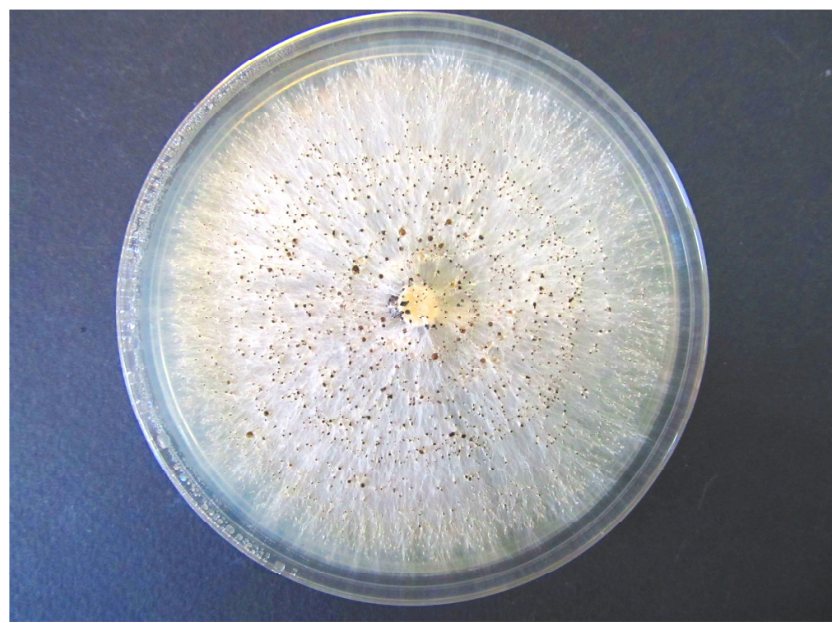

Fig. 2. Mycelium of $P$. cystidiosus

experiment was the selection of the optimal incubation temperature and the type of substrate with the addition of hemp shives and energetic grass straw on which mycelium growth was the fastest.

\section{Materials and Methods}

\section{Experimentalsetup}

The experiment was carried out from January to April 2017 at the Biological Laboratory of the Department of Vegetable Crops, in the Faculty of Horticulture and Landscape Architecture, Poznań University of Life Sciences. All laboratory experiments were established in a fully randomized design, 3 replications in 2 series.

\section{Biological material}

The subject of research in all experiments was two strains of P. cystidiosus - B1 and B122 - from the Collection of Edible and Medicinal Mushrooms Department of Vegetable Crops, Poznań University of Life Sciences.

\section{Temperature of incubation}

Wheat agar medium was used in the experiment in Petri dishes $90 \mathrm{~mm}$ : wheat - extract from $200 \mathrm{~g}$ of wheat grains, 
158

$22 \mathrm{~g}$ of agar, $3 \mathrm{~g}$ of glucose per 1 litre of medium. The agar medium was inoculated with mycelium of $P$. cystidiosus.

Incubation of the mycelium was performed in a thermostat in the temperature range from 15 to $30{ }^{\circ} \mathrm{C}$ at intervals of every $5{ }^{\circ} \mathrm{C}$, relative humidity $80-90 \%$. The rate of mycelial growth was studied by measuring the diameter of the surface of the medium overgrown by mycelium. The measurements were to be performed on the 5th, 7th, 10th and 14th day of incubation.

\section{The type of substrate}

The control substrate was prepared from a wheat straw. In the experiment, the substrate with wheat straw and the addition of hemp shives and energetic grasses - Panicum virgatum $\mathrm{L}$. and Miscanthus $\times$ giganteus - in increasing amounts: 10, 20 and $30 \%$ were used. The substrate was prepared from a wheat straw and supplements cut into chaff $4-5 \mathrm{~cm}$ long. The substrate for the experiment was moistened to a moisture content of about 65\% using deionized water. The substrates were placed in the bacteriological test tubes and subjected to sterilization. After cooling to room temperature, the substrates were inoculated with a $1-\mathrm{cm}$ layer of granular mycelium. Tubes with inoculated substrates were placed in a thermostat, which were maintained at a temperature of $25^{\circ} \mathrm{C}$ and relative humidity $80-90 \%$. The incubation was carried out in darkness for 21 days. The measure of mycelium growth was the length of the substrate in a biological tube overgrown by hyphae after 7 th, 10th, 14th and 21th days of incubation.

\section{Statistical analysis}

The results of research were statistically analysed. When comparing the experimental results, the analysis of variance for factorial experiments was applied (STAT, level of significance $\alpha=0.05$ ).

\section{Results and Discussion}

\section{Temperature of incubation}

A comparison of the growth of mycelium of $P$. cystidiosus in various temperatures after 5 th, 7 th, 10th and 14th days of incubation is presented on Fig. 1. It has been shown that growth of mycelium on different temperature was various. The best growth of mycelium of $P$. cystidiosus occurred at the temperature of $25^{\circ} \mathrm{C}$. At the temperatures $30^{\circ} \mathrm{C}$ and $20^{\circ} \mathrm{C}$, mycelial growth was already significantly lower. At the temperature of $15^{\circ} \mathrm{C}$, mycelial growth was the lowest. This may be due to the fact that this mushroom in its natural environment grows in a sub-tropical climate and $30^{\circ} \mathrm{C}$ is too high a temperature, while $15-20^{\circ} \mathrm{C}$ too low for the proper growth of mycelium. Too low temperatures, i.e. below $22{ }^{\circ} \mathrm{C}$, and too high, i.e. above $28{ }^{\circ} \mathrm{C}$, inhibit the growth of mycelium. On the other hand, the longer-lasting temperature of $34-35{ }^{\circ} \mathrm{C}$ causes mycelium to decay (Ziombra 1996). Temperature $25{ }^{\circ} \mathrm{C}$ for growth of mycelium P. cystidiosus reccomends Stamets (2011). For the growth of mycelium, most species of oyster mushrooms are at a recommended temperature of $25^{\circ} \mathrm{C}$ (Ziombra, 1998; Siwulski and Sobieralski, 2004; Gapiński et al., 2007; Siwulski et al., 2007; Stamets, 2011). Chang and Hayes (1978) and Kalberer (1992) determine the optimal temperature depending on the oyster mushroom species in the range of $22-28^{\circ} \mathrm{C}$.

\section{The type of substrate}

A comparison of the growth of mycelium of $P$. cystidiosus on a substrate with Panicum virgatum in addition 10,20 and $30 \%$ is presented in Fig. 2. It has been shown that the growth of mycelium of $P$. cystidiosus on different substrates varied. The fastest growth of mycelium was on a substrate with a $20 \%$ and $30 \%$ addition of $P$. virgatum.

A comparison of the growth of mycelium of $P$. cystidiosus on a substrate with Miscanthus $\times$ giganteus in addition 10, 20 and $30 \%$ is presented in Fig. 3.

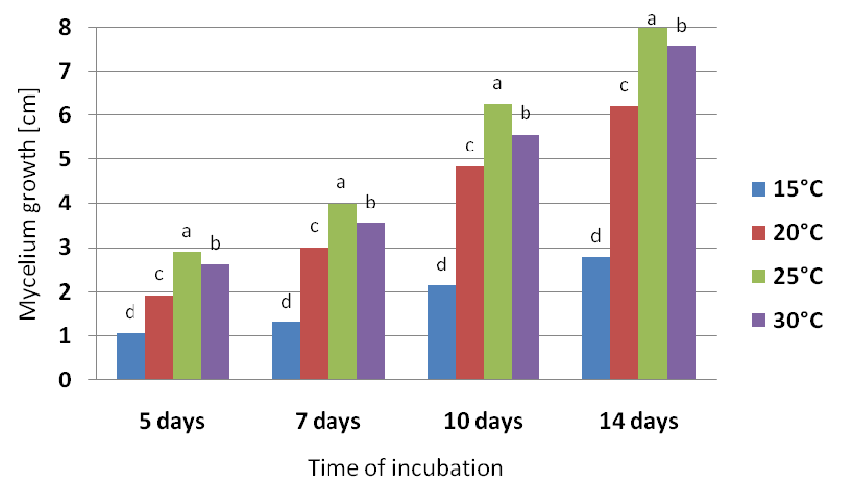

Fig. 1. A comparison of the growth of mycelium of $P$. cystidiosus in various temperatures

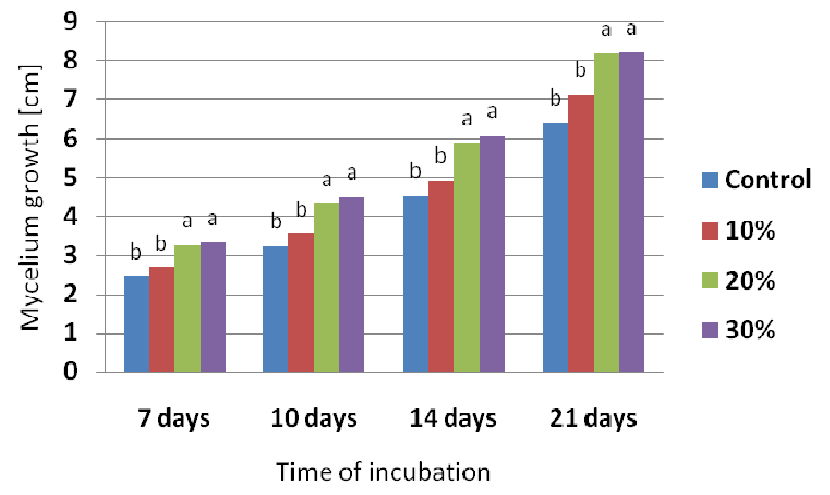

Fig. 2. A comparison of the growth of mycelium of $P$. cystidiosus in a substrate with the varied addition of $P$. virgatum

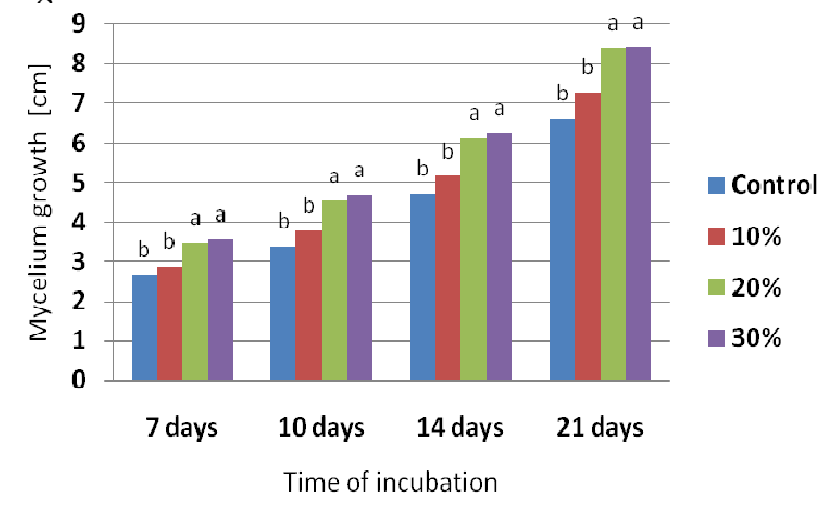

Fig. 3. A comparison of the growth of mycelium of $P$. cystidiosus in a substrate with the varied addiction of $M . \times$ giganteus 
It has been shown that the growth of mycelium of $P$. cystidiosus on different substrates varied. As in the case above, the fastest growth of mycelium was on a substrate with a $20 \%$ and $30 \%$ addition of $M . \times$ giganteus.

A comparison of the growth of mycelium of $P$. cystidiosus on a substrate with hemp shives in addition 10, 20 and $30 \%$ is presented in Fig. 4.

It has been shown that the growth of mycelium of $P$. cystidiosus on different substrates varied. The fastest growth of mycelium was on a substrate with $20 \%$ and $30 \%$ addition of hemp shives.

The mycelium growth of oyster mushrooms depends on many factors, among others: an agar medium, the incubation temperature, the type of substrate, additives, which also confirms the research of Ziombra (1998) and Gapiński et al. (2001). Previous self study has confirmed the use of hemp shives and energetic grass straw as a component of the substrate for many species of cultivated mushrooms. It has been shown that the growth of mycelium of this species and cultivars was dependent on the diversity of the growing substrate. It has been shown that the use of substrates from mixtures of various substrates and organic additives is preferable to homogeneous substrates because of the richer mycelial growth medium, greater nitrogen and carbon diversity, and improved water and air conditions resulting from a more complex substrate structure. Moreover, it was shown particularly useful Miscanthus sp. straw (the mycelium overgrew at a rapid rate, fruiting bodies were of good quality) due to the high content of easily available and assimilable compounds compared to other media (eg cellulose and simple sugars). In addition, it was confirmed that the usefulness of hemp shives and their antiseptic properties have been proven to inhibit the growth of competing organisms in relation to the mycelium cultivated mushrooms, providing a quick overgrowth of mycelium through the substrate while guaranteeing yield. Moreover, hemp shives have a structure of one-year wood and the concentration of lignin and cellulose used by cultivated mushrooms is much higher than in the commonly used in mushroom cultivation cereal straw. The specific spongy structure of hemp shives promotes good water absorption and retention, which prevents the substrate from drying out and stimulates mycelium growth and yield (Jasińska et al., 2010; Siwulski et al., 2010a; Siwulski et al., 2010b; Sobieralski et al., 2011; Jasińska et al.,

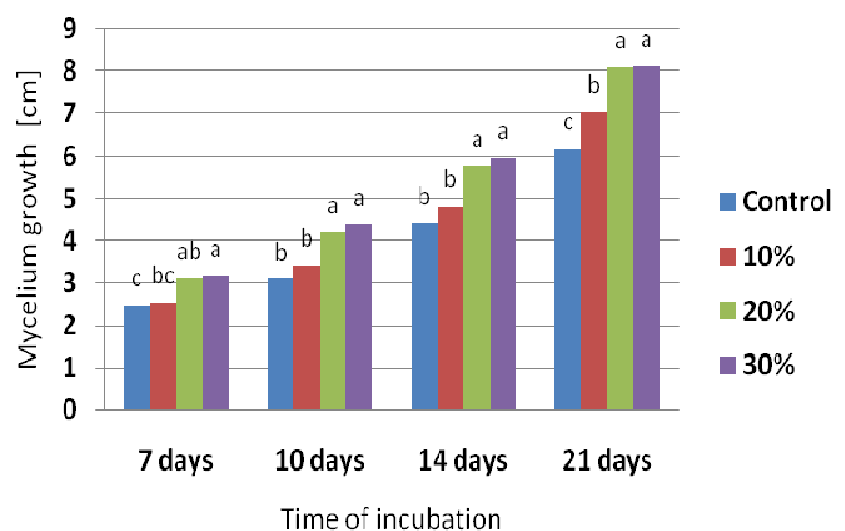

Fig. 4. A comparison of the growth of mycelium of $P$. cystidiosus in a substrate with a varied addition of hemp shives
2012; Siwulski et al., 2013; Jasińska et al., 2014a; Jasińska et al., 2014b). Use of waste materials from the textile industry and the straw of energetic grasses in mushroom cultivation is also described by Hadar et al. (1993), Pani et al. (1997), Kirbag and Akyuz (2008), Akyuz and Yildiz (2008).

\section{Conclusions}

The optimal incubation temperature for the growth of mycelium of $P$. cystidiosus was $25^{\circ} \mathrm{C}$. The best substrate for the growth of mycelium of $P$. cystidiosus was wheat straw with the addition of hemp shives, $P$. virgatum and $M$. x giganteus in amounts of 20 and $30 \%$.

\section{References}

Abdullah N, Ismail S, Aminudin N, Shuib A, Lau B (2012). Evaluation of Selected Culinary-Medicinal Mushrooms for Antioxidant and ACE Inhibitory Activities. Evidence-Based Complementary and Alternative Medicine 2012:1-12.

Akyuz M, Yildiz A (2008). Evaluation of cellulosic wastes for the cultivation of Pleurotus eryngii (DC. ex Fr.) Quel. African Journal of Biotechnology 7:14941499.

Bao D, Kinugasa S, Kitamoto Y (2004). The biological species of oyster mushrooms from Asia based on mating compatibility tests. Journal of WoodScience 50(2):162-168.

Chang ST, Hayes WA (1978). The biology and cultivation of edible mushrooms. Academic Press, New York.

Cohen R, Persky L, Handar Y (2002). Biotechnological applications and potential of wood-degrading mushrooms of the genus Pleurotus. Applied Microbiology and Biotechnology 58:582-94.

Croan S (2004). Conversion of conifer wastes into edible and medicinal mushrooms. Forest ProductsJournal 54(2):68-76.

Dawidowicz L, Siwulski M (2017). Comparsion of growth of mycelium of Pleurotus cystidiosus (Miller) on various agar media. Journal Agriculture and Forestry 63(1):61-68.

Gapiński M, Woźniak W, Ziombra M (2001). Boczniak. Technologia uprawy i przetwarzania [Oyster mushroom. Technology of cultivation and processing].PWRiL Press, Poznań.

Gapiński M, Woźniak W, Ziombra M, Murawska J (2007). Oyster mycelium on the liquid medium. Acta Mycologica42(1):125-128.

Hadar Y, Kerem Z, Grodecki B (1993). Biodegradation of lignocellulosic agricultural wastes by Pleurotus ostreatus. Journal of Biotechnology 30(1):133-139.

Hanelt P (2001). Mansfeld's Encyklopedia of Agricultural and Horticular Corps.Springer-Verlag Berlin Heidelberg 29-30.

Jasińska A, Siwullki M, Sobieralski K (2010). Straw of energy grasses Influence on the mycelium growth of black poplar mushroom Agrocybe aegerita (Brig.) Sing. In: VI International Scientific Conference for Students and PhD Students Lviv. Ukraine 21-24.09.2010, Abstract Book:139-140.

Jasińska A, Siwullki M, Sobieralski K (2012). Mycelium growth and yielding of Black Poplar Mushroom - Agrocybe aegerita (Brig.) Sing. on different substrates. Journal of Agricultural Science and Technology A(2):10401047. 
160

Jasińska A, Siwulski M, Sobieralski K, Majkkowski W, Rogalski J, Ohga S (2014a).Comparative study of mycelial growth and carpophore yield of Agrocybe aegerita (Brig.) Sing. on selected agricultural and textile industry wastes as a cultivation substrate. Journal of Faculty of Agriculture Kyushu University 59(1):5-11.

Jasińska A, Siwulski M, Sobieralski K, Rogalski J, Ohga S (2014b). Morphological and qualitative features of Agrocybe aegerita (Brig) Sing. carpophores cultivated on agricultural and textile industry wastes. Journal of Faculty of Agriculture Kyushu University 59(2):229-234.

Kalberer P (1992). Moderne Methoden des Pleurotus-Anbaus [Modern Methods of Pleurotus Cultivation]. Champignon 369:176-184.

Karaman M, Jovin E, Malbasa R, Matavuly M, Popovic M (2010). Medicinal and edible lignicolous fungi as natural sources of antioxidative and antibacterial agents. Phytotherapy Research 24(10):1473-1481.

Kirbag S, Akyuz M (2008). Evaluation of agricultural waste for the cultivation of Pleurotus erymgii (DC. ex Fr.) Quel. var. ferulae Lanzi. African Journal of Biotechnology 7:3660-3664.

Lau C, Abdullah N, Shuib A (2013). Novel angiotensin I-converting enzyme inhibitory peptides derived from an edible mushroom, Pleurotus cystidiosus OK Miller identified by LC-MS/MS. BMC Complementary and Alternative Medicine 13(1):1-10.

Lechner B, Wright J, Albertó E (2004). The genus Pleurotus in Argentina. Mycologia 96(4):845-858.

Manzi P, Pizzoferrato L (2000). ß-glucans in edible mushrooms. Food Chemistry 68(3):315-318.

Moncalvo J (1995). Pleurotus cystidiosus var. formosensis var. nov: an unusual Pleurotus collection of subgenus Coremiopleurotus from Taiwan. Mycological Research 99(12):1479-1482.

Pani B, Panda S, Das S (1997). Utilization of some by-products and other wastes for sporophore production of oyster mushroom. Orissa Journal Horticulture 25:36-39.

Patel Y,Naraian R, Singh V (2012). Medicinal properties of Pleurotus species (oyster mushroom): a review. World Journal of Fungal and Plant Biology3(1):01-12.

Petersen RH, Nicholl DB, Hughes KW (1997). Mating systems of some putative polypore-agaric relatives. Plant Systematics and Evolution 207(3-4):135-158.

Selvakumar P, Rajasekar S, Periasamy K, Raaman N (2008). Isolation and characterization of melanin pigment from Pleurotus cystidiosus (telomorph of Antromycopsis macrocarpa). World Journal of Microbiology and Biotechnology 24(10):2125-2131.

Siwulski M, Czerwińska A, Sobieralski K (2007). Comparison of mycelium growth and yielding of some Pleurotus spp. strains. Spontaneous and induced variation for the genetic improvement of horticultural crops. University of Technology and Life Science in Bydgoszcz, University Press pp335-339.

SiwulskiM,SobieralskiK (2004). Uprawa grzybów jadalnychileczniczych w warunkach naturalnych [Cultivation of edible and medicinal mushrooms in natural conditions]. Kurpisz Press, Poznań.

Siwulski M,Drzewiecka K, Sobieralski K, Chong Y (2010a). Comparison of growth and enzymatic activity of mycelium and yielding of Pleurotus ostreatus (Fr.) Kumm on different substrates. Acta Scientiarum
Polonorum Hortorum Cultus 9(3):45-50.

Siwulski M, Sobieralski K, MańkowskiJ (2010b). Comparison of mycelium growth of selected species of cultivated mushrooms on textile industry wastes. Acta Scientiarum Polonorum Hortorum Cultus 9(3):37-43.

Siwulski M, Sobieralski K, Sas-Golak I (2013). Wzrost grzybni oraz plon boczniaka ostrygowatego Pleurrotus ostreatus na materialach odpadowych przemystu włókienniczego [Mycelial growth and yield of Pleurotus ostreatus on the waste materials of the textile industry]. Pieczarki 2:76-79.

Siwulski M, Sobieralski K, Sas-Golak I (2014). Wartość odżywcza i prozdrowotna grzybów [Pro-health and nutritional value of mushrooms]. Żywność. Nauka. Technologia.Jakość 1(92):16-28.

Sobieralski K, Siwulski M, Sas-Golak I, Mańkowski J, Kotlińska T (2011). Mycelium growth and yield of wild strains of Pleurotus ostreatus (Jacq: Fr) Quel. cultivated on waste materials from textile industry. Folia Horticulturae 23(1):67-71.

Stamets $\mathrm{P}(2011)$. Growing gourmet and medicinal mushrooms. Ten Speed Press, Berkeley.

Thekkuttuparambil A, Kainoor K (2007). Indian medicinal mushrooms as a source of antioxidant and antitumoragents. Journal of Clinical Biochemistryand Nutrition 40(3):157-162.

Usami A, Motooka R, Nakahashi H, Okuno Y, Miyzzawa M (2014). Characteristic odorants from bailingu oyster mushroom (Pleurotus eryngii var. tuoliensis) and summer oyster mushroom (Pleurotus cystidiosus).Journal of Oleo Science 63(7):731-739.

Vilgalys R, Moncalvo J, Liou S, Volovsek M (1996). Recent advances in molecular systematics of the genus Pleurotus. Mushroom Biology and Products 1996:91-101.

Wasser S (2002). Medicinal mushrooms as a source of antitumor and immunomodulating polysaccharides. Applied Microbiology and Biotechnology 60:258-274.

Zervakis G (1998). Mating competence and biological species within the subgenus Coremiopleurotus. Mycologia 90:1063-1074.

Zervakis G, Balis C (1996). A pluralistic approach in the study of Pleurotus species with emphasis on compatibility and physiology of the European morphotaxa. Mycological Research 100(6):717-731.

Zervakis G, Moncalvo J, Vilgalys R (2004). Molecular phylogeny, biogeography and speciation of the mushroom species Pleurotus cystidiosus and allied taxa. Microbiology 150(3):715-726.

ZiombraM(1996). Wzrost grzybnii plonowanie kilku taksonów boczniaka na wybranych podlożach [Growth of mycelium and yielding of several cultivars of oyster mushrooms on a selected substrates]. In: Materiaty VI Zjazdu Hodowców Roślin Ogrodniczych "Hodowla roślin o podwyższonej jakości" [Proceedings of the 6th Congress of Horticultural Plant Breeders "Breeding plants with high quality"]. AR, Kraków 293-297.

Ziombra M (1998). Wplyw niektórych czynników na wzrost grzybni i plonowanie boczniaka [Effect of some factors on mycelial growth and yield of oyster mushrooms]. Rozprawy Naukowe AR Poznań 278:75. 